\title{
Penetrating the Entry Doctrine: Excludable Aliens' Constitutional Rights in Immigration Processes
}

\author{
Ethan A. Klingsberg
}

A brief outline of the current model of due process jurisprudence is necessary to understand the doctrine that denies a group of aliens constitutional protection in immigration processes. The Constitution requires courts to engage in procedural due process scrutiny" whenever a "core interest" - an interest in a right that precedent recognizes as inherent in "life, liberty or property"2 -is at stake. ${ }^{3}$ For example, if a court rules that the right to procreate is inherent in the meaning of "liberty" and potentially affected by the outcome of an adjudication, then the court will proceed to analyze what process is due under the Constitution to safeguard that liberty interest. At the minimum, courts usually find that some kind of hearing preceded by proper notice is necessary to protect a due process interest."

In defining the range of substantive rights protected by the due process clause, ${ }^{8}$ courts have consistently held that there is no inherent right to enter the United States. "This "entry doctrine" has serious consequences for excludable aliens, who, despite their physical presence in the United States, are legally considered to be detained at the border and still trying

1. Procedural due process scrutiny determines what safeguards are constitutionally required in a government adjudicatory structure; see infra note 71 . Procedural due process scrutiny results in no substantive remedies. Access to procedural due process has been of more significance since the 1950 's. See infra note 10.

2. See, e.g., Garcia-Mir v. Meese, 788 F.2d 1446, 1449 \& n.3, 1452-53 (11th Cir. 1986) (due process can be invoked by "a core liberty interest arising directly from the Fifth Amendment").

3. Substantive due process rights trigger procedural due process because they define "life, liberty or property." See Meyer v. Nebraska, 262 U.S. 390, 399 (1923) (listing substantive due process rights which constitute "liberty"), cited with approval in Board of Regents v. Roth, 408 U.S. 564, 572

(1972) (explaining workings of "core" or "inherent" approach to activating procedural due process).

4. Santosky v. Kramer, 455 U.S. 745, 753 (1982) ("process is constitutionally due" before government can interfere with fundamental liberty interest such as freedom of personal choice in matters of family life).

5. See Cleveland Bd. of Educ. v. Loudermill, 470 U.S. 532, 542 (1985) ("deprivation of life, liberty or property [must] 'be preceded by notice and opportunity for hearing appropriate to the nature of the case" " (quoting Mullane v. Central Hanover Bank \& Trust Co., 339 U.S. 306, 313 (1950))).

6. U.S Const, amends. V, XIV.

7. The source of the extraconstitutional status of an interest in entry is case law. See infra notes 27-39 and accompanying text. 
to enter. ${ }^{8}$ When excludable aliens have sought to establish a core interest for the purpose of challenging immigration procedures, courts have ruled that, because there is no inherent right to enter the country, excludable aliens need not be accorded due process. ${ }^{\circ}$

A plethora of commentary has criticized the entry doctrine for allowing courts to overlook unfair treatment of excludable aliens in immigration processes. ${ }^{10}$ Yet the courts have remained steadfast in refusing to accord

8. "Excludable alien" refers to any alien participating in an immigration process and not yet legally considercd to have entered the country. See Fernandez-Roque v. Smith, 734 F.2d 576, 578 n.2 (11th Cir. 1984) (defining excludable alien). An alien has "entered" the United States if he has been admitted lawfully under the Immigration and Nationality Act (INA) or has physically come into the country unlawfully by evading the admissions process. See In re Pierre, 14 I. \& N. Dec. 467 (1973) (setting forth test for determining whether "entry" has occurred when immigration officials confront alien near border); see also 8 U.S.C. $\$ 1101(\mathrm{a})(13)$ (1982) (partially defining entry). Excludable aliens physically within United States territory are either at the border, in a detention center, or on parole. This Note does not address the legal rights of those excludable aliens outside of the country; see Henkin, The Constitution as Compact and as Conscience: Individual Rights Abroad and at Our Gates, 27 WM. \& MARY L. REv. 11 (1985) (discussing whether aliens physically outside of United States territory can possess legal rights). Courts undoubtedly possess the power to vindicate the constitutional rights of aliens who are within United States territory; see infra note 13; infra notes 34-39 and accompanying text; $c f$. infra note 30 (courts enforce constitutional rights despite Executive's interests in border control and national security).

Once aliens complete "entry" by either lawful or unlawful means, their status changes from excludable to deportable. See The Japanese Immigrant Case, 189 U.S. 86, 100-01 (1902) (due process protects deportable alien's right to remain in country, but would not protect interest in entry).

9. See infra notes $27-39$ and accompanying text.

10. See, e.g., 2 K. Davis, Administrative Law $\$ 11.5$, at 358 (2d ed. 1979) (entry doctrine precedents are "shocking"); Hart, The Power of Congress to Limit the Jurisdiction of the Federal Courts: An Exercise in Dialectic, 66 HARv. L. REv. 1362, 1387-96 (1953) (entry doctrine is "patently presposterous" because access to due process scrutiny should be intrinsic in judicial review and not be dependent upon presence of core right to enter); Note, Constitutional Limits on the Power to Exclude Aliens, 82 ColuM. L. Rev. 957 (1982) (excludable aliens should receive constitutional protections because natural law theory dictates that government involvement should lead to constitutional protections); Note, The Constitutional Rights of Excluded Aliens: Proposed Limits on the Indefinite Detention of the Cuban Refugees, 70 GEo. L.J. 1303 (1982) (proposing that courts abolish distinction between excludable aliens and deportable aliens because former have inherent constitutional rights in non-immigration contexts and entry doctrine is abusive); Note, The Constitutional Rights of Excludable Aliens: History Provides a Refuge, 61 WASH. L. Rev. 1449 (1986) (courts should treat excludable aliens" constitutional challenges like original deportable alien precedents); Developments in the Law-Immigration Policy and Aliens, 96 Harv. L. Rev. 1286, 1322-24 (1983) (condernning entry doctrine as "anomaly" and proposing that excludable aliens with "contacts" to United States receive due process protection).

Most entry doctrine criticism appeared only recently because access to due process has only recently presented the prospect of courts ordering the implementation of significant procedural safeguards. When the Court provided the foundation for the entry doctrine in the nineteenth century, see Nishimura Ekiu v. United States, 142 U.S. 651, 660 (1892) (first case to decide that there is no right to enter), post-entrant aliens only received a modest deportation process to protect their constitutional rights. See The Japanese Immigrant Case, 189 U.S. 86, 101-02 (1902) (due process requires neither interpreter for one who cannot understand English nor formal notice and hearing). A half century later, the process constitutionally due a deportable alien was radically different. See, e.g., Wong Yang Sun v. McGrath, 339 U.S. 33 (1950) (due process violated if deportation proceedings adjudicated by INS officials).

This Note, unlike previous commentary, does not attempt to debunk the entry doctrinc. Assuming that the entry doctrine is valid, this Note establishes two significant areas in which the entry doctrine's bar to constitutional protections may be limited: (1) where a life, liberty, or property interest is present that a court construes as distinct from an interest in entry; (2) where government action has created an interest of constitutional proportions on an excludable alien's behalf. See infra notes 27-57 and accompanying text. 
excludable aliens core interests in matters related to entry. ${ }^{11}$ In particular, courts continue to distinguish the inherent interests of excludable aliens in immigration processes from the interests of deportable aliens, whom the courts recognize as having a distinct interest in remaining in the country, ${ }^{12}$ and the interests of all persons outside the immigration setting, a realm where an interest in entry is not pertinent. ${ }^{13}$

In light of the failure of courts to recognize a core interest in entry, an alternative approach to determining when a due process interest is present could improve the plight of excludable aliens. Since 1970, courts have developed and increasingly relied upon the entitlement model to activate procedural due process. As explicitly outlined in Board of Regents $v$. Roth ${ }^{14}$ the entitlement approach necessitates procedurai due process protections whenever the government creates a legitimate expectation that substantive standards will guide a decision of whether to grant a benefit. ${ }^{15}$ For example, in Roth's companion case, Perry $v$. Sinderman, ${ }^{16}$ a state college policy provided that certain standards would guide the decisionmaking process on whether to rehire faculty. The Supreme Court held that procedural due process safeguards were necessary to protect the teacher's legitimate expectation of (or entitlement to) a decision in accordance with the prescribed standards. Only if a substantively fettered decisionmaking structure exists will a court find an entitlement interest. Courts examine primarily authoritative sources, like statutes and rules,

11. See infra notes $27-39$ and accompanying text.

12. See supra note 8 (explaining distinction between excludable and deportable aliens and basis for deportable aliens' due process interests in immigration proceedings).

13. See, e.g., Russian Volunteer Fleet v. United States, 282 U.S. 481 (1931) (recognizing constitutional rights of aliens located abroad in non-immigration context); United States v. Henry, 604 F.2d 908, 912-14 (Sth Cir. 1979) (excludable alien is entitled to Fifth Amendment protection in federal criminal proceeding).

Although appealing to humanitarian concerns, scholarly commentary has been unpersuasive to courts because the proposed reasons for activating due process fail to include any precedent that can overcome the nonexistence of an inherent right to enter. See, e.g., Jean v. Nelson, 727 F.2d 957, 967-75 ( 11 th Cir.) (en banc) (following entry doctrine in context of challenge to parole process), aff $d$ on other grounds, 472 U.S. 846 (1985); see also Amanullah v. Nelson, 811 F.2d 1 (1st Cir. 1987) (following entry doctrine in challenge to parole process); Garcia-Mir v. Meese, 788 F.2d 1446, 1455 (11th Cir. 1986) (same), cert. denied, 107 S. Ct. 289 (1987). The entry doctrine was cited without reconsideration in Landon v. Plasencia, 459 U.S. 21, 32 (1982) (challenge to admissions process by excludable alien claiming to be reentering).

14. 408 U.S. 564, 576-78 (1972).

15. Id. at 576-78. Although the respondent in Roth did not have a justified expectation, the Roth decision set forth the criterion for future recognition of due process interests based entirely on government action without any reference to the "brutal need" factor which played a key role in Goldberg v. Kelly, 397 U.S. 254 (1970) (due process for welfare recipients). See alsa Olim v. Wakinekona, 461 U.S. 238, 249-50 (1983) (only expectations of receiving substantive benefit create entitlements; expectations that government will engage in procedure cannot create entitlements); Hermann, The New Litierty: The Procedural Due Process Rights of Prisoners and Others Under the Burger Court, 59 N.Y.U. L. REv. 482 (1984) (examining rise of government-created liberty interests); Diver, The Wrath of Roth (Book Review), 94 YALE L.J. 1529, 1538-41 (1985) (discussing "the Roth Court's infamous entitlement trigger"); infra notes 16-17, 41-43, 61, 107, 117 and accompanying text (explaining developments in entitlement theory).

16. 408 U.S. 593 (1972). 
and never the subjective, unilateral desires of the applicant, to assess the legitimacy of an expectation. ${ }^{17}$ Decisionmaking processes under three major provisions of the Immigration and Nationality Act (INA)-withholding of return, ${ }^{18}$ immediate relative status, ${ }^{19}$ and parole ${ }^{20}$-appear to satisfy the Roth criterion for government-created due process interests. Even excludable aliens appear to possess entitlement interests in having these three remedies adjudicated with procedural due process protections.

But courts have yet to decide whether the entry doctrine permits excludable aliens to use entitlement interests to invoke due process. Circuit court opinions have underscored the need to resolve this open question. ${ }^{21}$ Most recently, a class of excludable aliens challenging immigration procedures presented the Eleventh Circuit with a claim that an entitlement interest had been created on their behalf by a speech President Carter delivered. ${ }^{22}$ The government relied on two defenses. First, it argued that excludable aliens could not possess interests to activate due process in an immigration context. ${ }^{23}$ Second, it contended that the President's speech did not create any entitlement interests under the progeny of Roth. ${ }^{24}$ The Eleventh Circuit adopted the government's second argument, and thus there was no need to address the more complex question of whether excludable aliens could ever rely on entitlement interests to invoke procedural due process protection. ${ }^{25}$ Significantly, the court commented that, to consider whether excludable aliens could validly use Roth entitlements to seek procedural due process protections, courts would first have to engage in the "arduous task" of "completely unravelling and then considering all of the permutations of this question" by "searching the penumbras and interstices of the various immigration law cases." 26 This Note undertakes that task.

17. Roth, 408 U.S. at 577 (identifying entitlement interest through reference to "independent sources such as state law" and not by reference to "need," "desire," or "unilateral expectation").

18. 8 U.S.C. \& 1253(h) (1982).

19. 8 U.S.C. $\$ 1154(1982)$.

20. 8 U.S.C. $\$ 1182$ (d)(5)(A) (1982).

21. Garcia-Mir v. Meese, 788 F.2d 1446, 1450 (11th Gir. 1986) (noting difficulty which court would face if it had to resolve complex question of whether entry doctrine precludes due process protection of entitlement interests); see also Augustin v. Sava, 735 F.2d 32, 37-38 (2d Cir. 1984) (dictum referring to government-created due process interests that excludable aliens "may well" be able to use).

Whether entitlements related to interests in entry activate due process scrutiny is a federal constitutional question for courts to resolve and not subject to whether Congress intended or expected these entitlements to trigger due process. $C f$. Cleveland Bd. of Educ. v. Loudermill, 470 U.S. 532, 540-41 (requiring due process protection of entitlement even though legislature which created entitlement did not intend to trigger constitutional scrutiny of procedures).

22. Garcia-Mir, 788 F.2d at 1448.

23. Id. at $1449-50$.

24. Id. at 1450-52 (citing Olim v. Wakinekona, 461 U.S. 238 (1983), and Connecticut Bd. of Pardons v. Dumschat, 452 U.S. 458 (1981)).

25. 788 F.2d at 1451 .

26. Id. at 1450 . 
In Section I, this Note analyzes the scope of the entry doctrine. Section II explores whether the entry doctrine precludes the application of the entitlement approach to due process. This Section relies upon both general due process jurisprudence and entry doctrine precedent to demonstrate that excludable aliens may possess valid entitlement interests in immigration remedies. Section III then assesses three important processes-withholding of return, immediate relative status, and parole-to show that excludable aliens do possess entitlement interests related to entry. In addition, Section III considers the controversial issues that would dominate "what process is due" analyses if excludable aliens choose to utilize their entitlement interests in these three remedies.

\section{The SCope of the Entry Doctrine}

The seminal case supporting the denial of procedural due process rights to excludable aliens is United States ex rel. Knauff v. Shaughnessy. ${ }^{27}$ Ellen Knauff challenged the denial of her application for admission because she never received a hearing. The Court first determined that the pertinent statutes did not provide for a hearing. ${ }^{28}$ Then, addressing Knauff's constitutional challenge, the Court pronounced the oft-quoted principle: "Whatever the procedure authorized by Congress is, it is due process as far as an alien denied entry is concerned." 29 The basis for this ruling was that an alien seeking admission into the United States has no inherent right of entry; therefore, this non-existent right cannot sustain a core interest entitled to due process protection. ${ }^{30}$

Subsequent case law has shed light on the scope of the Knauff principle, now called the "entry doctrine." In Shaughnessy v. United States ex rel. Mezei, ${ }^{31}$ an excludable alien had been denied admission without a hearing and placed in a detention facility. Justice Clark, writing for the Court, explained that the central issue raised by these facts was whether the government could continue to detain Mezei without having held a hearing on the merits of the decision to confine him. ${ }^{32}$ The Court declined

27. 338 U.S. 537 (1950).

28. Id. at 540-42 \& nn.1-3 (citing Act of May 22, 1918, ch. 81, 40 Stat. 559, as amended by Act of June 21,1941 , ch. $210, \S 1,55$ Stat. 252 (repealed 1952)).

29. Id. at 544 .

30. Id. at 542; see also Nishimura Ekiu v. United States, 142 U.S. 651,660 (1892) (no constitutuonal right to enter in substantive due process challenge); infra note 60 .

Judicial respect for the Executive's powers over national security and admissior, were not bases in Knauff and Shaughnessy v. United States ex rel. Mezei, 345 U.S. 206 (1953) (following Knauff), for barring access to the Constitution. The implication of government interests in national security and admission is not a ground for denying due process. See, e.g., Landon v. Plasencia, 459 U.S. 21, 34-35 (due process applies despite government's interests in sovereignty and "administration of the immigration laws at the border"); Kwong Hai Chew v. Colding, 344 U.S. 590 (1953) (powers over national security and admission at stake, but due process applies); see also infra note 37 and accompanying text (discussing aliens' rights at stake in Chew and Landon as distinguishable from interest in entry).

31. 345 U.S. 206 (1953).

32. Id. at 207 (issue is whether due process entitles Mezei to be released "on bond until arrange- 
to find an interest sufficient to invoke due process protections. The ground for this decision was reliance upon the Knauff principle that an alien arrives at the border without an interest in the right to enter. Thus, by characterizing Mezei's claim as only a variation of a claim to a core interest in the right to enter, the Court avoided recognition of his asserted liberty interest in freedom from detention. Recent circuit court decisions have relied upon the reasoning of Mezei to hold that excludable aliens' claims to various liberty interests in immigration processes merely constitute attempts to assert a core interest in a right to enter. ${ }^{33}$

Following the reasoning in Mezei, if a court characterizes an alien's interest as distinct from an asserted core interest in the right to enter, then the entry doctrine may not preclude invocation of due process protections. Thus, in recent cases where courts have found an inherent constitutional interest that is not simply a variant of the right to enter, they have granted due process protections to excludable aliens in admissions related processes. For example, in Landon v. Plasencia, ${ }^{34}$ the Supreme Court reviewed an alien's procedural challenge to the exclusion proceeding in which the immigration judge denied her claim that she was a returning resident entitled to admission. ${ }^{38}$ The Court held that the alien, despite her placement in an exclusion hearing, had a core interest in the right to reenter at stake in the proceeding because she was trying to prove that she was a returning resident. ${ }^{36}$ Justice O'Connor, writing for the Court, deemed

ments are made for his departure abroad" because hearing never preceded decision to detain him); see Fernandez-Roque v. Smith, 734 F.2d 576, 581-82 (11th Cir. 1984) (explaining Mezei); Jean v. Nelson, 727 F.2d 957, 969-70 (11th Gir.) (en banc) (same), affd on other grounds, 472 U.S. 846 (1985).

33. These courts apply the entry doctrine even though the immigration processes in question have no direct relationship to legal "entry" or admission of the alien to the country. The basis for these decisions is the Mezei Court's application of the entry doctrine to preclude access to due process in a detention adjudication, even though detention and parole processes have only an indirect relationship to "entry." See Leng May Ma v. Barber, 357 U.S. 185 (1958) (whether government paroles or detains alien has no effect on whether alien has technically "entered"). While the immigration processes of parole and withholding of return are not directly linked to "entry" the progeny of Mezei holds that these pre-admission immigration processes are related to a right to enter for entry doctrine purposes. See, e.g., Jean, 727 F.2d at 969-70, 982 n.34 (reasoning from Mezei that non-existence of right to enter means excludable aliens lack inherent constitutional rights regarding applications for parole, asylum, and admission); Chun v. Sava, 708 F.2d 869, 876-77 (2d. Cir. 1983) (entry doctrine implies that excludable aliens have "very limited" inherent rights in withholding of return and asylum applications).

Even though neither parole nor withholding of return can modify pre-entry status, one can justify linking these processes to entry by their practical role in an excludable alien's continued presence in this country before an admission. See Fernandez-Rogue, 734 F.2d at 581-82 (parole decision constitutes integral part of admissions process); infra note 74 and accompanying text (connection between withholding of return and continued presence in United States).

34. 459 U.S. 21 (1982).

35 The Court first established that the INS had properly relegated Plasencia to an exclusion hearing because she could not be classified as a deportable alien and a "question of entry" was the issue presented by her admissions application. Id. at 28-32.

36. Id. at $32-34$. 
the entry doctrine inapplicable by distinguishing an interest in the right to reenter from an interest in the right to enter. ${ }^{37}$

Similarly, in Lynch v. Cannatella, the Fifth Gircuit recognized an excludable alien's due process interest in the right to be free from inhumane treatment in the immigration process because this interest is not derived from an interest in the right to enter ${ }^{38}$ Landon and Lynch clarify the scope of the entry doctrine of Knauff and Mezei. These recent decisions confirm that the entry doctrine is not a blanket preclusion of all due process interests of excludable aliens challenging immigration procedures. Rather, the courts must carefully assess in each case whether the due process interests are separate from an asserted core interest in a right to enter. $^{39}$

\section{THE Roth APPROACH}

\section{A. Compatibility with the Entry Doctrine}

Due process interests do not flow only from core rights. Parallel case law in non-immigration contexts demonstrates that it is possible to possess a valid Roth right to due process in a situation barren of core interests. In entry doctrine case law as well, the denial of due process protection for a lack of core interests does not preclude reliance on entitlement interests.

Roth held that a due process interest can arise entirely as a result of a legitimate expectation which the government creates by assuring applicants that substantive standards will guide a decision of whether to grant a benefit. ${ }^{40}$ The essential characteristic courts examine to detect the creation of a Roth interest is an indication that the final decision must be fettered by a clear, prescribed rule or rules. ${ }^{41}$ This kind of analysis en-

37. Id. at 33-34. The Court did not decide whether the excludable alien should be admitted, but did decide that the INS must resolve the question of whether she is a reentrant or an initial entrant in accordance with procedural due process. Id. at 28; see Kwong Hai Chew v. Colding, 344 U.S. 590, 600 (1952) (regardless of alien's technical classification, interest in reentry triggers due process).

38. 810 F.2d 1363, 1373-74 (5th Cir. 1987); see also Medina v. O'Neil, 589 F. Supp. 1028, 1032-33, 1040 (S.D. Tex. 1984) (excludable alien's due process interest in freedom from punishment can be recognized in challenge to INS detention procedure), rev'd on other grounds, 838 F.2d 800 (5th Cir. 1988). The precedent for these holdings is Wong Wing v. United States, 163 U.S. 228 (1896) (alien granted due process protection of interest in freedom from punishment authorized by immigration laws). In Wong IVing the alien was a post-entrant, but the holding was interpreted in Lynch and Medina to stand for the proposition that a claim to a core interest in freedom from punishment is not a variation on a claim to a core interest in the right to enter.

In Gul v. Sava, No. 88-1220 (E.D.N.Y. filed April 20, 1988), the district cour may confront this same issue. The government is trying to use the entry doctrine as a ground for dismissing this constitutional challenge by excludable aliens to the allegedly inhumane conditions of immigration detention in New York area hotels.

39. For a discussion of the core interests that entry doctrine precedents have construed as related to entry, sec supra note 33 and accompanying text.

40. See supra note 15 and accompanying text.

41. See, e.g., Meachum v. Fano, 427 U.S. 215, 226-29 (1976) (no interest because substance of final decision subject to adjudicator's "unfettered discretion"); see also infra notes 107 and 117 and accompanving text (discussing entitlement approach). 
ables courts to discern entitlement interests without any reference to the presence of core interests. Hence in Perry, the standards provided by the college to guide rehiring decisions created a due process interest for the professor regardless of whether there is an inherent right to future employment. ${ }^{42}$ Similarly, the absence of a core interest in a right to enter should not automatically deprive excludable aliens of due process interests when immigration statutes create justifiable expectations.

Indeed, the availability of the entitlement interest approach may be discerned from the discussion of the entry doctrine in Knauff and Mezei. ${ }^{43}$ In Knauff, ${ }^{44}$ the Court's determination that the excludable alien possessed no inherent interest in entering the United States did not completely resolve her procedural due process claim to a hearing on her application for admission. The final section of the Court's opinion implicitly recognized that, by statute, the government could have conferred upon Knauff rights that would "relieve [her] of her alien status," in due process interests related to her admissions application. ${ }^{46}$ The Court declined to find a statutorily created interest entitling Knauff to due process protection only because the War Brides Act ${ }^{47}$ expressly permitted the government to deny a war bride admission for any reason. ${ }^{48}$

Mezei reaffirmed that Knauff's holding denying excludable aliens an inherent right to enter does not preclude the presence of a governmentcreated, due process interest related to that right. In justifying the denial of procedural due process in Mezei, the Court stated that "any right to enter the United States depends upon the Congressional will." ${ }^{\prime 9}$ Signifi-

42. See supra notes $15-17$ and accompanying text; see also Board of Pardons v. Allen, $107 \mathrm{~S}$. Ct 2415, 2417-22 (1987) (parole applicant possesses entitlement interest in state parole process even - though no core right to parole exists); Greenholtz v. Inmates of Neb. Penal Complex. 442 U.S. 1, 7. 12 (1979) (same).

43. The proposition that the Court foreshadowed the entitlement approach in the 1950's in Knauff and Mezei is supported by Professor Charles Reich's reliance on cases primarily from the same era to outline the jurisprudential roots of government-created due process interests. Reich, The New Property, 73 YALE L.J. 733 (1963); see also Slochower v. Board of Educ., 350 U.S. 551, $555-56,559$ (1956) (no absolute right to government employment, but due process interest created by conditions of employment set by authorities), cited with approval in Roth, 408 U.S. 564, 576 (1972).

44. See supra notes $27-30$ and accompanying text.

45. United States ex rel. Knauff v. Shaughnessy, 338 U.S. 537, 546 (1950).

46. See supra notes $27-30$ and accompanying text (one of alien status lacks inherent due process interests related to entry).

47. War Brides Act of 1945, Pub. L. No. 79-271, 59 Stat. 659 (1945) (expired 1948).

48. Id. Had the provisions of the War Brides Act conferred upon Knauff an interest in entry by promising admission 10 those who could prove they were war brides, then her denial of admission without a hearing would have violated her government-created due process right. This aspect of Knauff's claim to a due process interest parallels that of the excludable alien in United States ex rel. Paktorovics v. Murff, 260 F.2d 610 (2d Cir. 1958); see infra notes 51-55 and accompanying text. The crucial difference is that government action in Knauff induced no legitimate expectations because of the provisions stating that the United States could deny admission to a war bride on any grounds, while the government action in Paktorovics did create legitimate expectations.

49. Shaughnessy v. United States ex rel. Mezei, 345 U.S. 206, 216 (1953).

$A$ scenario in which all property and liberty rights are granted by the sovereign has been critucized as repugnant to American notions of inherent rights. L. TRIBE, AMERICAN Consturutional. Law $\$$ $10-12$, at 708 (2d ed. 1988). Yet this is exactly the situation of the excludable alien in many admis- 
cantly, the Court did not state that a right to enter can never exist, but implied that legislation could create an entitlement to such a right. ${ }^{50}$

The principle that procedural due process protects an excludable alien's expectations created by government action was recognized directly by the Second Circuit a few years after Mezei. In United States ex rel. Paktorovics v. Murff, ${ }^{51}$ that court determined that the federal government had made firm and substantive promises to Hungarian refugees regarding their admission to the United States. ${ }^{\mathbf{5 2}}$ Paktorovics challenged the procedures followed in the denial of his application for parole after he had arrived at the United States border and been placed in detention. The court found that the process by which parole was denied was permissible under the immigration laws. ${ }^{53}$ Nevertheless, the court held that Paktorovics, an excludable alien, was entitled to procedural due process protection on the ground that he possessed a liberty interest which the government's substantive promises had created. ${ }^{54}$ The court declined to apply the entry doctrine. Unlike the excludable aliens in Mezei and Knauff, who were held to have no inherent right to enter, Paktorovics's interest was the product of government action. While the Paktorovics decision pre-dated the articulation of the entitlement approach in Roth, the Second Circuit foreshadowed the concept of protecting legitimate expectations induced by government action. ${ }^{\mathrm{s5}}$

Recently, the Second Circuit has referred to interests in admissions related processes that excludable aliens "may well" possess, based on the application of Roth and its progeny. ${ }^{58}$ In these cases, procedural challenges were resolved on statutory grounds, with the "guidance" of due

sions related contexts-lacking a core interest while being able to derive an entitlement interest from government action. Professor Reich describes feudal, Nazi, and Soviet legal systems as similarly denying the presence of inherent rights, while recognizing rights dependent upon government action for their existence. Reich, supra note 43 , at 769-71.

50. The references in Knauff and Mezei to the possibility of a government-created right to enter did not concern merely whether excludable aliens could ever be entitled to enter. Both cases were procedural challenges arising under the Constitution; the discussion of the possibility of a right to enter in the context of these cases referred to a right to enter that would be protected by procedural due process. See supra notes 1-4 and accompanying text (outlining significance of substantive right in context of procedural challenge).

51. 260 F.2d 610 (2d Cir. 1958).

52. Id. at 613-14 (President's speech followed by congressional resolution induces refugees' legitimate expectations).

53. Id. at $614-15$.

54. Id. at 613-14.

55. See also supra note 43 (discussing predecessors of Roth during same lime period). Under contemporary entitlement interest analysis, it is questionable whether the government action in Paktorovics would be deemed sufficient to induce a legitimate expectation and thereby create a due process interest. Cf. Garcia-Mir v. Meese, 788 F.2d 1446, 1451 \& n.5 (11th Cir. 1986) (President's speech insufficient to create due process interest under entitlement approach). But such a contention concerning what meets the criteria for an entitlement interest under the progeny of Roth does not address the relationship between the entry doctrine's scope and the Second Circuit's use of the entitlement approach to due process in Paktorovics.

56. Augustin v. Sava, 735 F.2d 32, 37 (2d Cir. 1984) (challenge to withholding of return process); Chun v. Sava, 708 F.2d 869, 877 \& n.26 (2d Cir. 1983) (same). 
process requirements. ${ }^{57}$ These opinions lend further support to the applicability of the entitlement interest approach where excludable aliens do not possess any core interests.

\section{B. Possible Obstacles}

Although entry doctrine precedent permits excludable aliens to utilize the Roth approach, specific developments within the progeny of Roth may affect a court's application of the entitlement theory to excludable aliens' interests. The Supreme Court has suggested two circumstances that may preclude the recognition of entitlement interests: (1) when the deprivation of the benefit will have minor consequences; and (2) when the decision is "traditionally entrusted to the expertise" of the adjudicator. ${ }^{58}$ These two factors should not affect the application of the Roth doctrine to immigration provisions.

The minor benefit characteristic does not apply to entitlements in admissions related processes, because the remedies there have major consequences for excludable aliens. ${ }^{59}$ Precedent discussing the absence of aliens' inherent constitutional rights does not detract from the significance of the potential benefits offered to excludable aliens by immigration processes. These cases hold that excludable aliens have little to lose in the admissions process because they have yet to establish meaningful ties to this country. ${ }^{60}$ The entitlement approach, however, concerns the prospective interest in legitimately expected benefits. ${ }^{61}$ Accordingly, an excludable alien

57. Augustin, 735 F.2d at 37 ; Chun, 708 F.2d at $877 \&$ n.26.

58. Hewitt v. Helms, 459 U.S. 460,470 (1983). These factors do not function as absolute exceptions to the recognition of Roth interests. See, e.g., Thompson v. Kentucky Dept. of Corrections, 833 .F.2d.614, 618 (6th Cir. 1987) ("state may create a liberty interest in freedom from even relatively minor deprivations"), cert. granted, 108 S. Ct. 2869 (1988).

59. See infra note 71 (discussing private interests at stake in withholding of return, immediate relative status, and parole).

60. See, e.g., The Japanese Immigrant Case, 189 U.S. 86, 100-02 (1903) (holding that interests of those who have yet to "enter" are not constitutionally significant because meaningful ties to country have not yet been established).

61. See Board of Pardons v. Allen, 107 S. Ct. 2415, 2417-22 (1987) (state parole applicant does not have presently enjoyed benefits at stake, but Court refrains from invoking minor benefit exception and recognizes entitlement in expected, future benefit of release).

Roth's statement that the entitlement approach's purpose is to protect "the security of interests that a person has already acquired," could be interpreted to limit the entitlement approach's scope to due process protection of those interests in an already possessed benefit. Roth, 408 U.S. at 576 . Both L. TRIBE, supra note $49, \$ 10-9$, at 690 , and Comment, Entitlement, Enjoyment, \& Due Process of Law, 1974 DuKE L.J. 89, 111-14, argue that endorsement of such a principle of present enjoyment is inconsistent with the entitlement approach to due process interests. Since an entitlement interest springs not merely from an individual need but from the structure of a process, the Roth approach has not distinguished between the legitimacy of government-created expectations in regard to applications for initial benefits and continuations of benefits. See, e.g., Greenholtz v. Inmates of Neb. Penal Complex, 442 U.S. 1, 12 (1979) (recognizing entitlement interest in not-yet-possessed benefit of parole release); Wolff v. McDonnell, 418 U.S. 539 (1974) (protecting state-created liberty interest in prisoner's forthcoming freedom from incarceration). Only in the Greenholtz Court's discussions concerning the existence of a core interest and the nature of the safeguards required by due process did the principle of present enjoyment serve as a reference point. 442 U.S. at 9; see also Gregory v. Pittsfield, 470 U.S. 1018, 1018, 1021 (1985) (O'Connor, J., dissenting from denial of certiorari) (noting that 
who possesses an entitlement interest in an admissions related process would be able to demonstrate that the benefits expected are not so insignificant as to fall within this exception.

In Hewitt v. Helms, ${ }^{62}$ the Supreme Court suggested another possible exception to the general entitlement rule: when adjudicators may use their expertise to such an extent that they may base decisions upon standards not included in the promulgated criteria. ${ }^{63}$ The standards for confining a prisoner to administrative segregation created an entitlement interest in Hewitt. Yet the Court noted that there may be circumstances in the context of prison operations where an entitlement would not exist, despite codified standards, because the unfettered expertise of prison officials traditionally governed the adjudication. ${ }^{64}$ Thus, designated standards must guide the results of all decisions for a Roth interest to be present. ${ }^{65}$

Solidly established precedent refers to the deference of both Congress and the judiciary to the expertise of immigration officials. ${ }^{68}$ Immigration officials can manifest their expertise by establishing procedures and by implementing and interpreting the precise meaning of proper substantive criteria. ${ }^{67}$ However, this deference is to a type of expertise that is entirely different from the expertise addressed in Hewitt. Under the case law, immigration adjudicators may not use their expertise as an excuse to ignore requirements-which are provided for in statutes, regulations, or other authoritative sources-that certain substantive standards guide decisions. ${ }^{68}$ Accordingly, administrative expertise does not bar recognition of entitlement interests in immigration processes. ${ }^{69}$

State court's adherence to present enjoyment principle in determining whether entitlement interests are present is "questionable reading of [Supreme] Court precedent," contrary to "weight of authority among lower courts," and "unsettling in implication").

62. 459 U.S. 460 (1993).

63. Id. at 470 .

64. Id.

65. However, the standards need not be "applied mechanically." Board of Pardons v. Allen, 107 S.Cl. 2415, 2419 (1987).

66. See, e.g., INS v. Abudu, 108 S. Ct. 904, 914-15 (1988) ("INS officials must exercise especially sensitive political functions. . . [T]herefore the reasons for giving deference to agency decisions on petitions for reopening or reconsideration in other administrative contexts apply with even greater force in the INS context").

67. See 8 U.S.C. $\$ 1103$ (1982) (Attorney General's power to implement necessary immigration pracedures); see, e.g.. Amanullah v. Nelson, 811 F.2d 1 (1st Cir. 1987) (deferring to immigration officials' interpretation of substantive standards).

68. See, e.g., Abudu, 108 S. Ct. at 915 (while deferring to INS on adjudication of petitions for reopening, noting that immigration judge still must follow requirements of regulations); Jean $v$. Nelson, 472 U.S. 846,857 (1985) (remanded with instructions to assure that immigration parole adjudications conform to promulgated standards).

69. Moreover, deference to the plenary power over immigration should not prevent the Roth approach Irom triggering procedural due process scrutiny. Courts have recognized Roth interests in immigration contexts. See Ali v. INS, 661 F. Supp. 1234, 1246-47 \& n.6 (D. Mass. 1986) (immediate relative status); Orantes-Hernandez v. Meese, 685 F. Supp. 1488, 1506 (C.D.Cal. 1988) (withholding of r.turn). Other "plenary" powers do not function as obstacles to the recognition of Roth interests. See Thomas v. Board of Trustees, 515 F. Supp. 280, 286-287 \& n.7 (S.D. Tex. 1981) ("plenary" power of reassignment enjoyed by Board cannot block creation of Roth interest on teacher's behaln); City of Sault Ste. Marie v. Andrus, 458 F. Supp. 465, 474 (D.D.C. 1978) (despite Congress's "ple- 


\section{Excludable Aliens' ENTitlement Interests in the IMMIGRATION PROCESS}

Section II demonstrated that entry doctrine and due process jurisprudence permit excludable aliens to possess entitlement interests when government action creates legitimate expectations in immigration processes. This Section asserts that expectations of an entitlement nature $e^{70}$ actually exist in three major immigration processes: withholding of return, immediate relative status, and parole. In addition, this Section contends that each of these processes lacks certain procedural safeguards to which excludable aliens could claim due process rights pursuant to their entitlement interests. ${ }^{71}$

nary power" in managing Indian land, Roth interest can still be created). Cf. supra note 30 (compatibility of power over admission with procedural due process scrutiny).

70. See supra notes 15-17, 41-43 and accompanying text (discussing Roth and its progeny); infra notes 107,117 and accompanying text (same).

All Roth interests can disappear with a reform of the decisionmaking structure that results in the elimination of the standards which fetter discretion. It is unlikely that legislators and rulemakers will attempt to restructure the three remedies discussed by this Note. In particular, policymakers are likely to refrain from modifying the substantive structure of the withholding of return process, because the statutory entitlement is rooted in the requirements of an international treaty to which the United States is a ratified signatory. See INS v. Cardoza-Fonseca, 107 S. Ct. 1207, 1212 n.7 (1987) (citing United Nations Convention Relating to Refugees, 1954, art. 33.1, T.I.A.S. No. 6577, 189 U.N.T.S. 150, 176).

Legislators and rulemakers are also unlikely to eliminate entitlement interests in immigration processes to avoid procedural due process requirements. Due process safeguards need not conflict with the interests of immigration policymakers. See Simon, Liberty $\&$ Property in the Supreme Court: $A$ Defense of Roth and Perry, 71 CAL. L. REv. 146, 191 (1983) (Roth approach is not "inconsistent with the underlying legislative goal" because "Roth require[s] procedural protections only where the legislature [or another rulemaking authority] itself has designated the recipients of the benefits in question"); see also Landon v. Plasencia, 459 U.S. 21, 34-37 \& n.9 (1982) (in realm of immigration, courts should strictly adhere to constraints on "what process is due" test that are based upon deference to government interests); Mathews v. Eldridge, 424 U.S. 319, 348 (1976) (not requiring extensive procedural safeguards in part because of deference to fiscal concerns); Goss v. Lopez, 419 U.S. 565 (1975) (purpose of statute preserved in resolving what procedures required by Constitution). But see Schuck, The Transformation of Immigration Law, 84 ColuM. L. REv. 1, 68, 82-83 (1984) (extensive procedural safeguards may only cause delay); Simon, The Ideology of Advocacy: Procedural Justice and Professional Ethics, 1978 WIS. L. REv. 29, 113-30 (procedural safeguards can frustrate dignity of process).

71. This Note does not reach definitive conclusions regarding what process a court would find due under the Mathews $v$. Eldridge, 424 U.S. 319 (1976), test after procedural due process has been invoked by an entitlement interest. See id. (weighing government interest, private interest and risk of error to determine what safeguards due process requires); see also Landon v. Plasencia, 459 U.S. 21, 34 (1982) (Mathews test appropriate for implementing procedural due process in immigration context). See generally Mashaw, The Supreme Court's Due Process Calculus for Administrative Adjudication in Mathews v. Eldridge: Three Factors in Search of a Theory of Value, 44 U. CHI. L. REv. 28, 37-47 (1976) ("Ip]ervasive indeterminacies" plague "what process is due" formula because based upon "unanswerable questions"); Verkuil, A Study of Immigration Procedures, 31 UCLA L. RFV. 1141,1149 (1984) ("[i]n this ancertain environment, the contours of flexible due process are difficult to fix with confidence").

Each of the three Mathews factors is so significant in immigration processes in which excludable aliens participate that courts could reach widely varying results. The private interests in withholding of return, immediate relative status and parole can be, respectively, one's life, one's family and one's freedom from detention. The government interest in any immigration process is national sovereignty. The risks of error in reaching accurate decisions on applications for withholding of return, immediate relative status and parole are also high. The INS must determine, respectively, whether certain conditions in a foreign country endanger an individual's life or liberty, whether a marriage is a sham, and 


\section{A. Withholding of Return}

The withholding of return statute provides excludable aliens with the opportunity to stop the United States from returning them to any country in which they would face political persecution. ${ }^{72}$ All excludable aliens denied admission to the United States have opportunities to submit withholding of return applications. ${ }^{73}$ If a withholding of return application is successful, then the United States permits the alien to remain here until a more friendly nation can be found to accept him or her. ${ }^{74}$

The substantive structure of the decisionmaking process satisfies Roth criteria because the statute limits the discretion of an adjudicator to grant or withhold this remedy to an explicit list of standards. The statute mandates the approval of an application whenever an "alien's life or freedom would be threatened . . . on account of race, religion, nationality, membership in a particular social group, or political opinion,"75 as long as the alien has never "participated in . . . persecution," "serious crime"-or acts "danger[ous] to the security of the United States."76 The statute thereby creates a legitimate expectation that established standards will be followed in withholding of return adjudications. ${ }^{77}$ Whether this Roth interest is vi-

how the alten will behave in the future.

In Subsections III(A) and III(B), results of the Mathews calculus in analogous procedural due proses rhallenges by deportable aliens to withholding of return and immediate relative status adjudications serve as indicators of what safeguards would constitutionally be due excludable aliens with entitlement interests. This analogy is sound because the factors in the Mathews test are similar for lurth excludable and deportable aliens in these two processes. The government interest and risk of error factors are clearly the same in both deportable and excludable alien adjudications on withholding of return and immediate relative status. Also, courts should not rely on the differing constitutional sunificance of the private interests of excludable and deportable aliens to distinguish the weights of the pruvate interests of excludable and deportable aliens in the Mathews formula. See Mathews, 424 L'S. at $332,335,339-42$ (even though no core interest in receiving welfare, weight of private need con idered in determination of what process is due); Goldberg v. Kelly, 397 U.S. 254 (1970) (same). Excludable and deportable aliens' private interests in life and family in these two adjudications are pritentiallv of equal weight. Furthermore, aliens of both classifications can be physically in the country and risk significant ties by a denial of withholding of return or immediate relative status. The entry ductrine"s portraval of the significance of an excludable alien's ties to this country applies only to the determination of whether a due process interest exists, not to the weighing of one's private interest atter a duc process interest has been found.

728 L.S.C. $\$ 1253(\mathrm{~h})(1982)$. See infra text accompanying notes $75-76$.

73 [ I S.C. $\$ 1253(\mathrm{~h})$. In fiscal year 1986, 2,241 excludable aliens were denied any type of admission to the United States in formal exclusion proceedings, telephone interview with Margaret sullivan. Statistical Analysis Branch of the INS (January 5, 1988); 7,882 aliens were denied asylum in separate proceedings, 1986 STATISTICAL Y.B. OF THE INS 48 (1987) (asylum figure includes deportable and excludable aliens).

it Sec Exile on Varick Street: Excludable Aliens Fight a Desperate Battle, Village Voice, Dec. 27, 1087. at 17. col. 3 (American Immigration Lawyers Association spokesperson states that many ext ludable aliens denied asylum (form of admission) will be able to remain in United States through surcisful wathholding of return applications).

7ร 8 L.S.C. $\$ 1253(\mathrm{~h})(1)(1982)$.

76. 8 L'S.C. \$ 1253(h)(2) (1982).

77 See Orantes-Hernandez v. Meese, 685 F. Supp. 1488, 1506 (C.D. Cal. 1988) (recognizing constitutional interest created by withholding of return statute in deportable alien case: "entitlement to this mandatory relief constitutes a separate interest"); see also INS v. Cardoza-Fonseca, $107 \mathrm{~S}$. Ct. 1207,1219 (1987) (discussing entitlement nature of withholding of return's decisionmaking process). (ivurts have implied in dicta that the withholding statute satisfies Roth criteria in excludable alien 
able for excludable aliens is likely to be tested in the near future. Currently the United States is attempting to return 2,746 Mariel Cubans to their homeland.$^{78}$ In the wake of the recent riots by Mariel Cubans, particular attention will be paid to the procedures used to adjudicate individually their withholding applications. ${ }^{79}$

Challenges may also be made to procedures other than those specifically used to resolve the excludable Marielito withholding applications. Excludable aliens apply for withholding of return at an exclusion proceeding. ${ }^{80}$ Even though exclusion hearings offer many safeguards, ${ }^{81}$ important issues of procedural due process have yet to be resolved in the context of these proceedings: the lack of automatic notice of the right to petition for withholding of return, ${ }^{82}$ the role of State Department Reports in assessing the validity of applications, ${ }^{88}$ the lack of the right to appointed free counsel, ${ }^{84}$ and the sufficiency of notice of when the hearing will take place. ${ }^{85}$

cases. See, e.g., Jean v. Nelson, 727 F.2d 957, 981 n.33 (11th Cir.), affd on other grounds, 472 U.S. 846 (1985); Augustin v. Sava, 735 F.2d 32, 37-38 (2d Cir. 1984); Chun v. Sava, 708 F.2d 869, 876-77 \& n.25 (2d Cir. 1983).

78. Helton, What's Fair For The Cubans, N.Y. Times, Dec. 1, 1987, at A27, col. 2.

79. Id. Although many of the detained Mariel Cubans had withholding applications denied ycars ago, many may now try to resubmit withholding applications in light of new developments in Cuba. Withholding applications can be reopened under 8 C.F.R. $\$ 211$ (1988). Procedural duc process should apply to the reopening decision because the entitlement to withholding is at stake in this decision.

80. See 8 C.F.R. $\$ \$ 208.3(b), 208.11,236.3$ (1988).

81. 8 U.S.C. $\$ 1226$ (1982), 8 C.F.R. $\$ 236.2$ (1988). Exclusion proceedings include the following safeguards: a hearing before a Justice Department immigration judge who is independent of the INS enforcement hierarchy; and the rights to be represented by counsel, call witnesses, present evidence and cross-examine government witnesses.

82. Currently such a notice is given only if the immigration judge identifies the case as one pertinent to such a claim. See Jean v. Nelson, 727 F.2d 957, 983 n.35 (11th Cir.) (en banc), affd on other grounds, 472 U.S. 846 (1985). There have been mixed results in analogous suits brought by deportable aliens claiming the right to receive automatic notice of the opportunity to apply for asylum and for withholding of return in deportation proceedings. Ramirez-Osorio v. INS, 745 F.2d 937 (5th Cir. 1984) (no notice required); Orantes-Hernandez v. Meese, 685 F.Supp. 1488 (C.D. Cal. 1988) (notice required); Nunez v. Boldin, 537 F.Supp. 578 (S.D. Tex. 1982) (notice required).

83. The State Department provides "generic reports" on human rights in each nation to aid all withholding of return adjudications, and "individual reports" assessing how a specific applicant would be treated in a nation to aid selected adjudications. BHRHA Cuts Down Advisory Opinions, 64 Interpreter Releases 1215 (1987). A generic country report can be disregarded by an immigration judge, In $r e$ Sibrun, 19 I. \& N. Dec. No. 2932 (Jan. 29, 1983), and can also be misleading where an individual has a unique situation. Potential constitutional issues raised by these reports include whether due process requires an individualized report whenever requested, and whether due process requires a State Department report which is not biased by the United States' current relations with the foreign nation. Judge Friendly criticized State Department reports as unreliable and inappropriate in Zamora v. INS, 534 F.2d 1055, 1062-63 (2d Cir. 1976), but in this case brought by deportable aliens, the extensive safeguards available at deportation hearings were held to be sufficient to compensate for any infringement upon due process caused by the reports. Id. at 1059-60.

One scholar suggests that due process might require notice-and-comment rulemaking procedures to precede the use of generic reports. Verkuil, supra note 71 , at 1171-73.

84. 8 C.F.R. $\$ 236(1988)$ requires the INS to provide all those in exclusion proceedings with a list of free legal services. Note, Right to Appointed Counsel In Asylum Proceedings, 85 Colum. L. REV. 1157 (1986), argues that only appointed legal counsel is sufficient under due process standards when asylum and withtolding applications are at stake. See also Orantes-Hernandez v. Meese, 685 F. Supp. 1488 (C.D. Cal. 1988) (not requiring appointed counsel, but declaring INS policies that interfere with access to counsel to violate due process interests of deportable aliens applying for asylum and withholding).

85. Deportation hearings have a seven day notice requirement, while an exclusion proceeding has 
The Justice Department is currently attempting to revise the withholding application process for both excludable and deportable aliens. ${ }^{86} \mathrm{~A}$ recent proposal was withdrawn because of widespread criticism that procedural due process protections were not present in the plan. ${ }^{87}$ Should a future proposal add protections for deportable aliens but not excludable aliens ${ }^{88}$ it is possible that a Roth-based challenge may be brought successfully.

\section{B. Immediate Relative Status}

One of the only visa statuses which results in the benefit of admission, rather than a preference status subject to a quota, is that of an immediate relative to a citizen. ${ }^{89}$ Immediate relatives make up the largest single class of immigrants to the United States. ${ }^{90}$ More than half of all immediate relative status immigrants are spouses; the majority of whom are excludable aliens while their immediate relative petitions are pending. ${ }^{91}$ The statute mandates that an application for an immediate relative visa be approved if the standard for being a bona fide immediate relative is met. ${ }^{92}$ Such fettered discretion satisfies the Roth criteria. $^{93}$

In the process that determines whether the alien is a participant in a bona fide marriage, the Immigration and Naturalization Service (INS)

none. 8 U.S.C. $\$ \S 1225$ (B), 1226, 1252(b)(1) (1982); 8 C.F.R. $\$ \$ 236,242$ (1988); see Landon v. Plasencia, 459 U.S. 21, 38-41 (Marshall, J., dissenting) (discussing procedural due process problems presented by this aspect of exclusion proceedings).

86. See Recent Developments, 64 Interpreter Releases 1214 (1987).

87. See 52 Fed. Reg. 32,552 (1987) (to be codified at 8 C.F.R. § 108) (proposed Aug. 28, 1987); Recent Developments, 64 Interpreter Releases 1214 (1987) (announcement withdrawing proposed regulation and commentary). The most controversial aspect of the proposal was the replacement of independent Immigration Judges with INS officials. See, e.g., Keep the Immigration Judges in Place, N.Y. Times, Oct. 27, 1987, at A34, col. 1 (editorial). See also Wong Yang Sung v. MrGrath, 339 U.S. 33 (1950) (use of non-independent adjudicators in deportation proceedings violates due process).

88. This would happen if the Attorney General believes that he has to respond to the procedural due process concerns of only deportable aliens. See supra notes 22-26 and accompanying text (government contends that excludable aliens can never possess due process interests even if entitlement present).

89. 8 U.S.C. $\$ \S 1151(b), 1154$ (1982); 8 C.F.R. $\S 205$ (1988); see infra note 92.

90. 1986 Statistical Y.B. OF THE INS (1987) 8-11.

91. In fiscal year $1986,223,468$ aliens were admitted as immediate relatives of citizens; 137,597 of those were spouses; 74,662 of the spouses were new arrivals. Id. at 9 . In fiscal year 1986, 26,581 immediate relative petitions were denied. Statistical Analysis Branch, 1987 INS AdjudicATION SuMMARY REPORT 6. This denial rate is approximately twice the overall denial rate of $10 \%$ in visa petition processes. Martin, Mandel, Cheng Fan Kwok, and Other Unappealing Cases: The Next Frontier of Immigration Reform, 27 VA. J. INT'L L. 803, 821 n.41 (1987).

92. 8 U.S.C. $\$ 1154(\mathrm{~b})(1982)$ states: "After an investigation of the facts . ... the Attorney General shall, if he determines that the facts stated in the petition are true and that the alien in behalf of whom the petition is made is an immediate relative specified in section 1151(b) . ., approve the petition ...."

93. See Ali v. INS, 661 F. Supp. 1234, 1246 n.6 (D. Mass. 1986) (due process interest in immediate relative status process exists under entitlement approach for deportable alien). 
has been accused of disregarding many procedural due process safeguards. ${ }^{94}$ In response to a suit brought by deportable aliens with core interests at stake, a consent decree was entered which provides for elaborate procedural protections in regard to all marriage petitions submitted by aliens seeking immediate relative status in the New York INS district. ${ }^{95}$ The INS does not yet guarantee these safeguards in other regions. If excludable aliens utilized their entitlement interest to challenge the immediate relative status process, particularly the bona fide marriage petition process, it is possible that the due process protections required in New York would be made applicable in other regions.

Although it might appear plausible for the citizen-spouse rather than the excludable alien-spouse to bring a constitutional challenge, courts have not always recognized the legitimacy of a citizen's interests in an alien's immigration applications. In Knauff and Mezei, the Supreme Court disregarded any possible constitutional interests of a citizen husband and a permanent resident wife, respectively. ${ }^{98}$ More recently, the lower courts have split on the issue of whether a citizen has a constitutional interest in an alien-spouse's visa petition. ${ }^{97}$ Overall, the availability of Roth entitlements could lead the judiciary to require significant alterations of current INS practices concerning the immediate relative status adjudicatory process.

\section{G. Parole}

Immigration parole ${ }^{88}$ is a process of great import to excludable aliens. Many excludable aliens spend several years in the United States exhausting all of the opportunities offered by the admissions process. Theoretically, excludable aliens can remain in the United States indefinitely after having been denied all avenues of admission because no other country will

94. See, e.g., Id. at 1251 (describing alleged due process violations).

95. Stokes v. United States, 393 F.Supp. 24 (S.D.N.Y 1975); see also Ali, 661 F.Supp. at 1251 (commenting upon consent judgment entered by Stokes court). The Stokes consent decree required the INS to implement the following safeguards: written notice to parties of their rights; the rights to present evidence and live witnesses, cross-examine and rebut adverse evidence, inspect a verbatim record of the proceedings, subpoena witnesses and documents, and receive a decision based solely on evidence of record. A consent decree entered in Tanvir v. Nelson, No. 84-2212 (E.D.N.Y. decree entered June 19, 1984) further required the INS in the New York district to contact an applicant's attorney before any contact with the applicant. IMMIGRATION PROJECT OF THE NATIONAL LAWYeRS Guild, Immigration Law \& DefEnSE 4-36, 4-37 \& n.87 (1988).

96. See supra notes $27-33$ and accompanying text.

97. See Burrafato v. United States, 523 F.2d 554 (2d Cir. 1975), cert. denied, 424 U.S. 910 (1976) (no constitutional right of citizen-spouse at stake in excludable alien's visa petition); Ben-Issa v. Reagan, 645 F.Supp. 1556,-1562 (W.D. Mich. 1986) (same); De Pena v. Kissinger, 409 F.Supp. 1182 (S.D.N.Y. 1976) (citizen-spouse has standing but no constitutional interest in having alien spouse enter); see also Fiallo v. Bell, 430 U.S. 787, 794-95 \& n.6, 798-99 (1977) (upholding denial of entry to citizen father's illegitimate children); of. Kleidienst v. Mandel, 408 U.S. 753, 794-95 (1972) (upon reviewing denial of alien's visa application to speak in United States, Court declines to give significant weight to citizens' First Amendment interests in hearing speech of alien). But see Ali, 661 F.Supp. at 1246 \& n.r (D. Mass. 1986) (both alien and citizen-spouse have constitutional interest in alien spouse's visa application); Stokes, 393 F.Supp. 24 (S.D.N.Y. 1975) (same).

98. 8 U.S.C. $\S 1182(\mathrm{~d})(5)(A)(1982)$. 
admit them at their border. ${ }^{98}$ The parole process determines whether excludable aliens spend this time that precedes their admission or departure in a United States community with a sponsor or in a detention center. ${ }^{\mathbf{1 0 0}}$ Although a Roth interest is not directly apparent from examination of statutory provisions, an analysis of the structure of the immigration parole decisionmaking process in light of recent Supreme Court precedents reveals that parole applicants arguably possess valid entitlement interests.

The parole process contains few procedural safeguards. The decision is based entirely upon an adjudicator's interview of the applicant and a review of his or her INS file. ${ }^{101}$ There is also no notice of the opportunity to apply for parole. ${ }^{102}$ If due process scrutiny were applied to the parole process for the purpose of protecting excludable aliens' Roth entitlement interests, the courts would almost certainly require the implementation of such basic safeguards as notice and hearing. ${ }^{103}$

In Garcia-Mir v. Meese, ${ }^{104}$ the Eleventh Circuit denied claims by excludable aliens to entitlement interests in the parole process, because the process was not fettered by substantive standards that would create legitimate expectations. ${ }^{105}$ The court relied on the parole statute which provides that the Attorney General "may" parole detained aliens. ${ }^{108}$ The use of the word "may" led the court to conclude that a decision can be based on predesignated standards, any additional standards or no standards at all. Such a decisionmaking process fails to create an entitlement interest because no legitimate expectations exist concerning the precise substantive standards that must be used by adjudicators.

Nevertheless, the unfettered statutory discretion of the Attorney General should not necessarily eliminate the opportunities for the creation of a Roth interest. In determining if legitimate expectations are created, the Supreme Court's entitlement analyses have focused on whether there is unfettered discretion in the authority charged with exercising the decision-

99. The facts of Mezei raised this possibility; see supra notes 31-33 and accompanying text. See also Rodriguez-Fernandez v. Wilkenson, 654 F.2d 1382 (10th Cir. 1981) (dictum discussing possibility that indefinite detention of excludable alien violates constitutional right to freedom from inhumane (reatment)

100. During fiscal year 1987, the INS detained 82,650 aliens and approved 16,165 parole applications, Telephone interview with Margaret Sullivan, supra note 73.

101. 8 U.S.C. $\$ 1182(\mathrm{~d})(5)(\Lambda)(1982) ; 8$ C.F.R. $\$ 212.5$ (1988).

102. Id.

103. See supra note 5 and accompanying text (minimum due process requirements).

104. 788 F.2d 1446 (11th Cir. 1986), cert. denied, 107 S. Ct. 289 (1987).

105. 788 F.2d at 1451-52. The bulk of the opinion addressed provisions specifically applicable to excludable Mariel Cubans, but the court also affirmed the district court's holding that no entitlement interest is created under the general immigration parole provisions. See also Fernandez-Roque v. Smith, 622 F. Supp. 887, 892-94 (N.D. Ga. 1985). This Note does not address evaluations of entitlements under the specific Mariel parole plan in use during 1985-86.

106. 8 U.S.C. $\$ 1182(d)(5)(A)(1982)$. 
making power over the applications, ${ }^{107}$ who in the parole process is the parole adjudicator and not the Attorney General. ${ }^{108}$

In Jean v. Nelson, ${ }^{109}$ the Supreme Court had occasion, in the context of an equal protection challenge, to address the discretionary power available to immigration parole adjudicators. The issue in Jean was whether adjudicators could deny parole based on the applicant's Haitian nationality. The Supreme Court affirmed the circuit court's conclusion that the parole process is structured in such a way that the adjudicators can only use the standards predesignated by their "superiors in Washington." 110 Since no standards authorizing discrimination based on nationality had been promulgated, the Court held that the adjudicators could not base a decision on the discriminatory standard alleged to have been used. ${ }^{111}$ The case was then remanded to the district court to determine whether the decision denying parole could be supported by the specifically promulgated standards. The Court's portrayal of the parole process contradicts the apparent "empty set" of standards upon which the statute implies parole decisions can be based. ${ }^{112}$

Jean v. Nelson represents the most authoritative precedent depicting the immigration parole process. Indeed, the court in Garcia-Mir relied upon Jean to support its denial of an entitlement interest in parole. Garcia-Mir ignored, however, the Jean opinion's reference to the necessity that the parole adjudicators follow only promulgated standards. The Garcia-Mir court assumed that a Roth interest in parole could not exist simply because Jean characterized the parole decisionmakers as having "broad discretion." 113

Significantly, a year after the Garcia-Mir decision on immigration parole, the Supreme Court in Board of Pardons v. Allen recognized that

107. Board of Pardons v. Dumschat, 452 U.S. 458,465 (1981) (domestic prison parole case explaining entitlement interest criteria); Id. at 467 (Brennan, J. concurring) (detection of entitlements in Perry and Roth focuses on decisionmaker); see also Brennan v. Cunningham, 813 F.2d 1, 8 (1st Cir. 1987) (entitlement interest in halfway house program determined by "look[ing] at the nature of the constraints on decisionmakers without requiring a particular formula of 'mandatory language." ").

108. The Attorney General delegates the power to adjudicate parole applications to low level decisionmakers. 8 C.F.R. $\$ 212.5$ (1988). The Attorney General has chosen not to delegate his unfettered statutory discretion. Apparently in the interest of uniformity, the Attorney General "circumscribes" the discretion of these designated decisionmakers. See infra notes 109-112 and accompanying text; infra note 118 .

109. 472 U.S. 846 (1985).

110. 727 F.2d 957. 978-79 (11th Cir. 1984) (discretion of adjudicators "circumscribed" by standards found in instructions rather than in statute or regulations), aff'd, 472 U.S. 846 (1985).

111. Id. at $978-80$.

112. 472 U.S. at 858 (Marshall, J., dissenting) (majority portrays parole decisions as restricted by sources and factors not apparent from statute); 727 F.2d at 985 (Tjoflat, J., dissenting) (majority's model of decisionmaking process "threatens to destroy the broad discretion" upon which statute permits parole decisions to be based).

113. 727 F.2d at 977. Even though Jean held that the parameters for parole decisions are limited, the decision still characterized the process as "discretionary" because of the generality of some of the standards available to adjudicators under 8 C.F.R. $\$ 212.5$ (1988) (standards include "the public interest" and avoidance of "security risk"). 
the characteristic of "broad discretion" is not necessarily incompatible with the creation of an entitlement interest. ${ }^{114}$ In the domestic parole process examined in Allen, decisionmakers also had wide discretion. Among the predesignated standards to be used were "the best interests of society" and avoidance of "detriment to the prisoner."115 Writing for the majority, Justice Brennan declared that even though these standards will result in subjectivity, they still create legitimate expectations sufficient for an entitlement interest. Only when discretion means that the decisionmaker is "simply not bound by standards set" in advance is there an absence of entitlement interests. ${ }^{116}$ As explained in Jean v. Nelson, immigration authorities designate standards from which parole adjudicators must choose in reaching a decision; therefore, the fact that the adjudicators have "discretion" in applying these standards does not bar the creation of entitlement interests. ${ }^{117}$

114. 107 S. Ct. 2415, 2418-21 \& n.10 (1987); see also Winsett v. McGinnes, 617 F.2d 996, 1006 (3d Cir. 1980) (en banc) ("'discretionary character" " not fatal to presence of entitlement interest as long as adjudicator's discretion is not "absolute"), cert. denied, 449 U.S. 1093 (1981). But see Francis v. Fox, 838 F.2d 1147, 1149 n.8 (11th Cir. 1988) ("Winsett gives insufficient consideration to the highly subjective nature of the prison authorities' decision").

115. Allen, 107 S.Ct. at 2420 (quoting Mont. Code ANN. $\S 46-23-201$ (1985)).

116. Id. at 2419 ("Discretion" created by subjective or general nature of standards differs from "discretion" emanating from absence of any mandatory standards; only the latter "discretion" eliminates entitlement. (quoting R. Dworkin, Taking Rights Seriously 32 (1977))); see also supra note 107 and accompanying text (restraints on decisionmakers, rather than mandatory language formula, are basis of entitlement interest).

117. Jean portrays an immigration parole adjudicator's discretion as fettered because the reasons for which a denial can be issued are limited by policy and practice. 727 F.2d 978-79. The immigration parole decisionmaking process is similar to that of the work-release program in Winsett, $617 \mathrm{~F} .2 \mathrm{~d}$ at 1005-07, and the halfway house program in Brennan v. Cunningham, 813 F.2d 1, 8 (1st Gir. 1987). Like Jean, Winsett held that adjudicators could not use certain factors-"unfavorable public reaction and legislative reprisal"- -because "no place has been provided for their consideration in the exercise of discretion whether to grant or deny a prisoner work release." 617 F.2d at 1007 . Winsett then held that such a decisionmaking process creates an entitlement interest: "Although . . . the regulations adopted do not exhaust the criteria pertinent to a decision whether or not to grant work release, it is by no means clear that the . . . [adjudicator] may, under the rules, invoke any criterion he chooses [in reaching a decision]." Id. at 1006-07. Policies and practices fettered the adjudicatory structure in Winsett. 617 F.2d at 1005-06. In Cunningham, no document "literally exclude[d] the possibility that a[n adjudication] . . could occur . . . for no reason at all," but evidence of state practice led to the conclusion that adjudicators were restricted from issuing decisions based on "criteria to which no allusion may be found in the regulation." 813 F.2d at 8 . Thus, an entitlement interest was present in Cunningham.

Even though the restrictions upon immigration parole discretion described by Jean only apply to reasons available for denial, circuit courts have held that restrictions upon reasons for denial are sufficient to create an entitlement interest. See Cunningham, 813 F.2d at 6-8 (entitlement interest present as result of restrictions on grounds for denial, even though in theory adjudicator can approve application for any reason); Scott v. Illinois Parole and Pardon Bd., 669 F.2d 1185, 1188-89 (7th Cir.) (same), cert. denied, 459 U.S. 1048 (1982).

Furthermore, the immigration parole regulations, 8 C.F.R. $\$ 212.5$ (1988), mandate that an adjudicator "should consider" a list of standards before reaching a parole decision. Although the list of criteria which follows this mandate is not exhaustive, the combination of such mandatory language and certain critcria was enough to create an entitlement interest in visitation privileges in Thompson v. Kentucky Dept. of Corrections, 833 F.2d 614, 619 (6th Cir. 1987), cert. granted, 108 S. Ct. 2869 (1988). However, opinions differ on whether "should" constitutes mandatory language. See, e.g., Culbert v. Young, 834 F.2d 624, 628-29 \& n.5 (7th Cir. 1987), cert denied, 108 S.Ct. 1296 (1988) (noting conflict with state court over whether use of "should" in domestic parole statute constitutes 
In future assessments of whether entitlement interests exist in the immigration parole process, courts should follow two steps in their analysis. First, they should look beyond the parole statute's language and examine the workings of the decisionmaking process itself to determine if legitimate expectations are created by the policies given so much weight in the Jean decision. Second, courts should not automatically conclude that parole applicants lack legitimate expectations simply because the process is "discretionary" in some respects. Under a proper analysis of the decisionmaking structure, immigration parole should be subject to due process scrutiny. ${ }^{118}$

\section{ConCLUSION}

The entry doctrine does not foreclose excludable aliens from validly invoking due process scrutiny in the immigration context when an interest distinct from a claim to an inherent right to enter is present. Furthermore, general due process jurisprudence and immigration precedents reveal that the entry doctrine does not bar excludable aliens from utilizing entitlement interests to activate procedural due process. Excludable aliens should have access to constitutional protections in three major immigration procedures-withholding of return, immediate relative status, and parole-because provisions under the INA create entitlement interests in the remedies offered by these processes. If excludable aliens use these interests in due process challenges, then courts may, for the first time, require the government to provide some fundamental procedural safeguards in admissions related processes.

mandate or recommendation).

118. So far no court has scrutinized sufficiently the specific workings of the most recently promulgated Mariel Cuban parole plan for this Note to determine whether the Mariclitos possess entitlement interests in parole. See 8 C.F.R. $\$ \S 212.12,212.13$ (1988). Although these new regulations purport to vest special Mariel parole adjudicators with the unfettered discretion described in the parole statuce, Jean revealed that the discretion of an immigration parole adjudicator can be significantly "( scribed" by "policies... established by the Attorney General and President" which are not mentioned in statutes or regulations. See 727 F.2d at 978-79. 